\title{
EDUCATION IN BOSNIA AND HERZEGOVINA: AN INTERVIEW WITH ANITA LUKENDA AND SLAVICA PAVLOVIČ
}

\author{
Vincentas Lamanauskas \\ Šiauliai University, Lithuania
}

This year on the $20^{\text {th }}-23^{\text {rd }}$ of October the third international scientific conference Pedagogy, Education and Instruction took place in Bosnia and Herzegovina. The conference was organised by Mostar university. To say more precisely, the main conference organiser was Department of Pedagogy of Faculty of Science and Education.

It is worth noticing, that Bosnia and Herzegovina is a Balkan region state, which consists of two historical regions - Bosnia and Herzegovina. Mostar in this case is basically considered the capital of Herzegovina, situated in a picturesque mountainous place near the river Neretva.

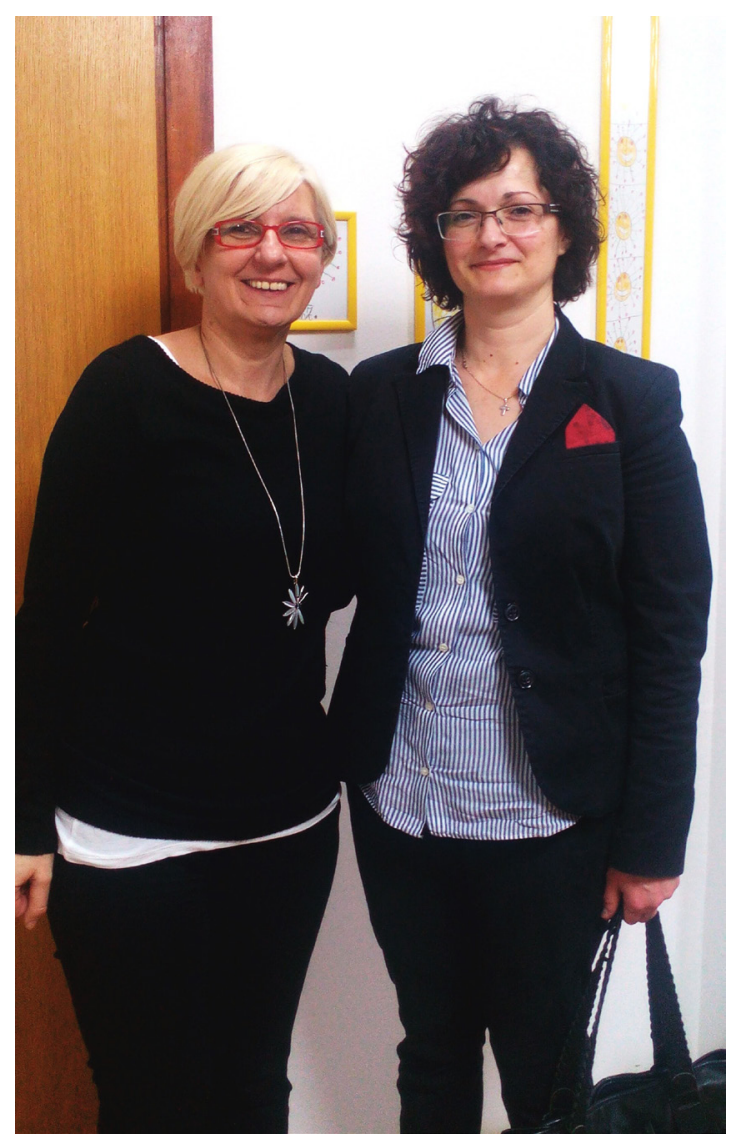

S. Pavlovič, A. Lukenda

\section{Anita Lukenda}

Senior assistant, areas of interest: International Education, Lifelong Learning, Educational Policy, Qualitative Methodology. Acting Head of Department of Pedagogy at faculty of Sciences and Education - University of Mostar.

\section{Slavica Pavlović}

Assistant professor, areas of interest: School Pedagogy, Pedagogy of Leisure, Statistics in Education, Pedagogy of Art, Sexual Education. 
It would be interesting to know a bird's-eye-view of the education system in your country in general, that is from primary to tertiary level. Can you describe the education system in your home country?

Anita and Slavica: According to the Dayton Peace Agreement (its Annex 4 is the Constitution of Bosnia and Herzegovina), brokered in 1995, Bosnia and Herzegovina is a decentralized country consisting of two entities, i.e. the Republic of Srpska (predominantly populated by the Serbs) and the Federation of Bosnia and Herzegovina (populated by the Bosniaks and the Croats), and the Brčko District. All the three peoples, namely the Serbs, Bosniaks and Croats are constituent peoples according to the Dayton Peace Agreement.

In the Republic of Srpska, the education policy is in the jurisdiction of its Ministry of Education, while in the Federation of Bosnia and Herzegovina ten different cantonal ministries of education are responsible for the educational policy.

In the Government of the Federation of Bosnia and Herzegovina there is a Ministry of Education, however, its role being mainly a coordinating one.

In the Brčko District the responsibility for the educational policy lays primarily within its Department of Education.

There is no ministry of education at the level of Bosnia and Herzegovina state. Ministry of Civil Affairs in the Council of Ministers of Bosnia and Herzegovina is responsible for concluding international agreements in the area of education as well as for representing Bosnia and Herzegovina at the international level with regard to the educational issues.

Concerning the levels of education, there is pre-school, primary, secondary and higher education. Educational reform agenda was made under the auspices of the international community in Bosnia and Herzegovina, namely the Peace Implementation Council for the implementation of the Dayton Peace Agreement tasked the OSCE Mission to Bosnia and Herzegovina to launch the educational reform process in 2002. Since then several framework laws in the area of pre-school, primary, secondary and higher education were passed at the level of Bosnia and Herzegovina. However, not all the necessary framework laws have been passed, like, for example, a framework law on the adult education. The lower levels of governance in $\mathrm{BiH}$ were obliged to harmonize their relevant laws with the framework ones.

Pre-school education is still not compulsory, and the number of the children enrolled is not very high.

According to the Framework Law on Primary and Secondary Education, from 2003, the former eight-year primary school was turned into nine-year one. Different parts of the country began with the nine-year primary education in different school years. An important part of the reform efforts was the introduction of the Common Core Curriculum in primary and only for the grammar schools (gimnazije) within the secondary education.

Secondary education consists of grammar schools, vocational secondary school, artistic secondary schools, technical secondary schools, religious secondary schools, and secondary schools for children with developmental disabilities. There are four grades and three grades secondary schools.

Although Bosnia and Herzegovina signed the Bologna Declaration in 2003, it was only in academic year of 2005/06 that the first universities introduced the studies in accordance with the Bologna process. The Framework Law on Higher Education was passed not before 2007 in the BiH Parliamentary Assembly. 
In Bosnia and Herzegovina there are public and private educational institutions.

It is obvious that teaching is a very important profession. Teachers need to be well educated. How teachers are educated in your country?

Anita and Slavica: Teachers of pre-school, primary and secondary level are educated at the teacher training faculties, faculties of natural sciences and education as well as at faculties of philosophy, which are integral parts of universities.

Since academic year 2008/09 pre-school teachers' education, which formally had lasted two or three years, was turned into a five-year study (two cycles varying $3+2$ or $4+1$ ). Primary education teachers (teaching from $1^{\text {st }}$ to $5^{\text {th }}$ grade) attend the university studies consisting of two cycles $(3+2$ or $4+1)$.

Specific subject teachers' education takes place at universities, according to the $3+2$ or $4+1$ model. It is possible to enroll in either a major or a double major teacher training studies.

\section{When should children start formal schooling in your country?}

Anita and Slavica: Since the new Framework Law on Primary and Secondary Education came into force, the required age for children to start formal schooling is six under condition they turned six before $1^{\text {st }}$ of April in the current calendar year.

It is a well-known fact that students' motivation to learn is a key element in education. If children are motivated to learn and if we enable each one to learn effectively, we will have an education system with a great performance level. What about students' motivation to learn in your country?

Anita and Slavica: It can be noticed that, in general, students' motivation is quite low. Anyway, (de)motivation should be subject of interdisciplinary research in our country.

What are the qualities of a good teacher from your point of view?

Anita and Slavica: The qualities of a good teacher are well-known in the scientific related literature. We consider one of the key ways to produce a good teacher is a serious selection process when entering the teacher university education. However, currently it is not being carried out in our country, at all.

It is clear that each country's education system has both advantages and disadvantages. Could you briefly describe your country's basic education system challenges?

Anita and Slavica: Basic challenges to educational system in Bosnia and Herzegovina are: quality of teacher induction and in-service education; civic education; intercultural education, the advantages of the ICT have not been used so far. Although Bosnia and Herzegovina has declared its commitment to lifelong learning policy, not much has been done in that area yet. 
I would like to sincerely thank colleagues Anita and Slavica for a greatly organized conference. Every conference is a great possibility to know yourself better, to try and to discover new, interesting educational approaches, to get acquainted with educational technology usage possibilities, finally just share ideas with the other country education theoretics and practitioners and acquire certain practical knowledge. On the other hand, participation in scientific conference is a perfect possibility to improve English knowledge, sociocultural competencies, to enter into collaborative relationship with the other country researchers and scientists, and also to introduce to Lithuania, Lithuanian education system. At the same time one can find out about the other country education system similarities and differences, strenghths and weaknesses, and of course, to contribute to innovative both Lithuania's and its education system image creation. More about visit to Bosnia and Herzegovina one can find on facebook address https://www.facebook.com/media/ set/?set=a.1480673691950062.1073741877.290054444345332\&type=3.

Note: This interview was performed 21 October 2016, in Mostar, Bosnia and Herzegovina.

Received 28 October 2016; accepted 26 December 2016

\begin{tabular}{l}
\hline Vincentas Lamanauskas \\
PhD., Professor, Department of Education \& Psychology, Siauliai University, P. Visinskio Street 25, \\
LT-76351 Siauliai, Lithuania. \\
E-mail: v.lamanauskas@ef.su.lt \\
Website: http://www.lamanauskas.puslapiai.lt
\end{tabular}

